\title{
Forest certification in Asia: The changing marketplace for value-added wood product manufacturers in China and Vietnam
}

\author{
by Tait Bowers ${ }^{1,2}$, Ivan Eastin ${ }^{1}$, Indroneil Ganguly ${ }^{1}$, Jeff $\mathrm{CaO}^{3}$ and Mihyun Seol ${ }^{4}$
}

\begin{abstract}
China and Vietnam have become two of the key wood manufacturers in Asia that export a large percentage of valueadded wood products globally. As regulations and environmental awareness from countries that import these products increase, manufacturers have had to establish certification practices for continued accessibility to these markets. A study based on managerial interviews and a survey with over 800 wood product manufacturing operations in China and Vietnam asked questions on how forest certification had been implemented in their business practices and what challenge had come from the adoption of these standards. These responses were analyzed to determine the contributing factors to the commitment to certification. Comparisons between China and Vietnam were used to identify country-specific factors that may influence a company's decision to obtain forest certification for its operations. Survey respondents indicated that acquiring certified raw material supply, market awareness, and certification costs were found to be the major constraints encountered in adding certified products to their sales mix. Lack of a domestic supply of certified wood was also a problem that led to a heavy reliance on imported wood at additional costs to the bottom line. Results revealed significant differences among the two countries regarding their perceptions of the benefits of certification, but showed that market benefits were the leading driver to a company's commitment to certification.
\end{abstract}

Key words: forest certification commitment, chain of custody, China and Vietnam wood manufacturers, certified wood product challenges and benefits

\section{RÉSUMÉ}

La Chine et le Vietnam sont devenus deux des principaux manufacturiers de bois de l'Asie qui exportent dans le monde un fort pourcentage de produits de bois à valeur ajoutée. Avec l'accroissement des règlements et de la sensibilisation environnementale des pays importateurs, les manufacturiers ont dû établir des pratiques de certification pour s’assurer l'accès continu à ces marchés. Une étude reposant sur des entrevues et un sondage des gestionnaires de plus de 800 entreprises de transformation en Chine et au Vietnam a voulu vérifier comment la certification forestière avait été implantée dans leurs pratiques d’affaires et quel défi avait découlé de l’adoption de ces normes. Les réponses ont été analysées afin de déterminer les facteurs ayant contribué à justifier un processus de certification. Les comparaisons entre la Chine et le Vietnam ont été utilisées pour identifier les facteurs propres à chaque pays qui ont pu influencer la décision des entreprises dobtenir une certification forestière de leurs opérations. Les répondants au sondage ont indiqué que lobtention d'un approvisionnement de bois brut certifié, la sensibilisation des marchés et les coûts de certification constituaient les principaux obstacles à l'ajout de produits certifiés à leurs éventail de produits destinés à la vente. Labsence d’approvisionnement domestique de bois certifié représentait également un problème qui a engendré une forte dépendance vis-à-vis des importations de bois qui ajoutait des coûts au bilan. Les résultats ont révélés des différences significatives entre les deux pays au niveau de leurs perceptions des bénéfices de la certification, mais ont indiqué que les bénéfices commerciaux constituaient lélément moteur de l'engagement d'une entreprise à obtenir une certification.

Mots clés : engagement envers une certification forestière, chaîne de possession, manufacturiers de bois de la Chine et du Vietnam, défis et bénéfices rattachés aux produits de bois certifiés

\footnotetext{
${ }^{1}$ Center for International Trade of Forest, Products (CINTRAFOR), University of Washington, Seattle, WA 98195, USA.

${ }^{2}$ Author to whom correspondence should be sent. E-mail: taitb@uw.edu.

${ }^{3}$ Asian Institute for Energy, Environment and Sustainability (AIEES), Seoul National University.

${ }^{4}$ Forest Carbon Policy Center for Forest and Climate Change, Korea Forest Research Institute, Seoul, 130-712, Republic of Korea.
} 


\section{Introduction}

Governments, NGOs and environmental groups are increasingly aware of the importance of building "good" forestry governance in order to substantially reduce deforestation rates and promote sustainable forestry (World Bank 2008). Forest certification was created in this context, as a "non-state market-driven" governance system aimed at influencing companies to comply with the rules and standards for sustainable forest management, through the promise of marketbased accessibility and profits, with public campaigns to pressure global companies to support forest certification (Cashore et al. 2004).

Since its inception in 1993, the Forest Stewardship Council (FSC) has emerged as the world's fastest-growing international forest certification scheme (FSC 2009). As of November 2009, FSC has issued over 15200 Chain of Custody (COC) certificates and 1000 Forest Management (FM) certificates with a total of 117 million ha of forests distributed in 82 countries, representing about $5 \%$ of the world's total productive forests (FSC 2009). However, one of critical tasks facing FSC and its supporters is to generate strong market signals and incentives to keep businesses committed to legal and sustainable forest management practices through FSC certification over a long term. FSC needs to further expand its raw material supply base, in both volume and species variety, as a way to meet the growing demand for FSC production and to bring down companies' sourcing costs. A major challenge facing FSC is the insurance of quality by certification bodies and the strict implementation of standards at the local level.

China and Vietnam represent the fastest-growing markets for FSC in Asia, driven by their booming export-oriented wood and furniture industries. China is processing and consuming nearly one-half of the world's forest products, even though less than $1 \%$ of the worlds' certified forests are located in this country. Vietnam has recently emerged onto the world's wood processing marketplace and imports about $80 \%$ of the timber it uses from overseas. The success of FSC in China and Vietnam has important implications for the overall success of FSC globally, and more broadly, the sustainability of global forest industries.

\section{Research Questions and Objectives}

Based on an online survey with FSC-COC certificate holders in China and Vietnam, this study seeks to accomplish the following tasks: a) to understand the recent market trends of forest industries in Asia and their impacts on forest certification developments in China and Vietnam, b) to evaluate FSC's benefits and constraints as they are perceived by FSC-COC operations in China and Vietnam, and c) to explore factors driving a company's long-term commitment to FSC.

One contribution of this study to forest certification literature is the empirical evidence from industries in Asia, which previously have not been adequately studied. Past research on forest certification has been largely focused on markets in developed nations such as Europe and North America (e.g., Karna et al 2003, Vidal et al. 2005, Owari et al 2006, Aguilar and Vlosky 2008), with only a limited focus on emerging markets in Asia. This study seeks to fill this void and provide updated information on the developments of forest certification in China and Vietnam. Results of this study may benefit international environmental organizations and certification bodies in search of marketing strategies in China and Vietnam as they continue to be two of the fastest growing markets in Asia for FSC.

\section{Background}

\section{Impact of globalization on forest industries in Asia}

Accelerated economic globalization and technological innovations since the 1960s have brought significant and irreversible changes to global forest products industries (Bael and Sedjo 2006). Asian forest products industries have undergone major structural changes that include the gradual decline of tropical plywood production in countries such as Indonesia and Malaysia, the rapid growth of the pulp and paper industry, China's rise into a world leading importer and exporter of forest products, and the increase in forest governance and environmental standards. According to statistics from FAO (2005), Asia is losing about $1 \%$ of its tropical forests each year. In response to growing concerns of illegal logging, the European Commission, governments of the USA and other countries have developed various trade policies to encourage responsible sourcing by timber importers. This attempt to eliminate illegal timber products from domestic and international markets has led to the creation of the EU FLEGT Action Plan and the amended Lacey Act, which prohibits the importation of illegally sourced forest products.

\section{Forest certification in China and Vietnam}

Asia comprises the world's major timber-producing countries (e.g., Indonesia, Malaysia), major wood-processing countries (China, Malaysia, Indonesia) and major wood fiber-consuming countries (e.g., China and Japan). Different political and social systems, land tenure, and local industries' general insensitivity to the environment, present significant challenges to the promotion of sustainable forestry practices and forest certification schemes in Asia (Cashore et al. 2006). Three forest certification schemes are currently active in China: FSC (Forest Stewardship Council), PEFC (Programme for Endorsement of Forest Certification schemes), and China's national forest certification scheme (CFCC); only FSC is active in Vietnam.

\section{FSC certification}

FSC is the world's largest forest certification program based on the number of certificate holders. FSC entered China in 1998 when it issued its first Chinese COC certificate. As of May 2012, there were 2001 FSC-COC certificate holders in China up from 621 in 2008 (an increase of over 200\%), making China the largest FSC-COC certificate holder in Asia, followed by Japan with 1134 (FSC 2012). Most of the FSC-certified forests in China have a timber production orientation with most Forest Management Units holding both FSC-FM and FSC-COC certificates, which allow them to sell raw materials to other FSC-COC companies in their supply chain. The dominance of FSC-certified forests in China may be attributable to two factors: lower transaction costs from wellmanaged forests and government's increased focus on the environment and social attributes of forest lands.

In regard to the first factor, Forest Management Units (FMUs) that already follow good forest management practices can save significant staffing costs from document preparation, employee training, and auditing. In China, most forest 
farms are government-owned and these forest bureaus are better managed and financed than smaller, collectively owned, private forests. Lower transaction costs allow these government-owned FMUs to be in a better position to obtain FSC certification than others who are lacking forest management experience and/or financial capabilities. These FMUs were a natural target by FSC and their allies at the early stages of market development.

The second factor is based on the Government's decreased focus on economic attributes of forestlands. Government officials and senior management of FMUs do not have the pressure to generate revenues from FSC sales. They place a high priority on environmental and social issues such as industry reputation and employment. FSC targets government organizations that are more interested in environmental and social interests associated with internationally recognized certification schemes. As the Chinese government furthers its forest land tenure reform aimed at encouraging good forest management practices and liberating domestic timber markets, the ownership structure of FSC-certified forests is expected to experience significant changes to include more private and collectively owned forests.

Forest certification was introduced to Vietnam during the country's rise as a major wood products processor and exporter. From years of war, Vietnam lost a significant proportion of its natural forests. The country's forest cover declined from $44 \%$ of the country's total land area in 1943 to $28 \%$ or 9.3 million hectares in 2000 (Butler 2009). The Vietnamese government has employed a series of forest rehabilitation measures, including a domestic logging ban, with a goal to establish 5 million ha of new forests (of which 2 million ha will be industrial wood plantations) between 1998 and 2010, and to restore forest cover of the country to the level of 1943 (de Jong, et al. 2010).

FSC is currently the only active forest certification scheme in Vietnam. As of May, 2012, 270 Vietnam-based companies have obtained FSC COC certificates. This is large compared to only one company in 2007. A lack of certified raw materials (particularly tropical timber) presents a major challenge to Vietnamese manufacturers. Today, most of the timber felled in Vietnam comes from forest plantations, with about $80 \%$ supplying the pulp and paper industry. The remaining higher-quality timber goes directly to the furniture and handicrafts sector (EIA/Telepak 2008). Currently, FSC-certified tropical timber is not being processed within Vietnam, so FSC outdoor furniture manufacturers have to rely on imports from other suppliers.

\section{PEFC certification}

The PEFC (Programme for Endorsement of Forest Certification) is an umbrella organization that endorses many national (in most cases government-backed) forest certification systems. This program ensures that local stakeholders' needs are met with consideration of national laws and regulations. PEFC awarded its first COC certificate in China in 2006. As of March 2012, 159 COC certificates have been issued under PEFC, up from 10 in 2007. China is in third place in Asia after Japan with 214 and Malaysia with 170 COC Certificates. PEFC has not issued any Forest Management certificates in China due in large part to the absence of recognized national forest management standards China.

\section{CFCC - China Forest Certification Council}

The creation and development of a national forest certification program in China can be seen as a result of the country's global integration process. The Chinese government started to participate in international forest certification conventions as early as 1995-the same year the country submitted an application to join the World Trade Organization. Following the $12^{\text {th }}$ Meeting of the Montreal Process Working Group in Beijing in November 2000, the Chinese government established a Forest Certification Department under the State Forestry Administration in 2001. Later, the China Forest Certification Council (CFCC) was founded as an administration agency to oversee the national system's development. The certification program that includes forest management and chain-of-custody certification standards was officially released in September 2007 by CFCC. Due to the lack of knowledgeable auditors and certification bodies, the program has yet to be fully implemented nationwide. The low awareness and acceptance of this program by international markets is of concern to CFCC, given the competition from FSC, but it is expected that CFCC will eventually be endorsed by PEFC.

\section{Long-term commitment to forest certification}

Customer pressure or requirements has been the main reason/motivation for companies to pursue forest certification. If customers stopped requesting proof of chain of custody, it is likely that many certified companies would not renew their certificates when they expire and utilize timber from unknown sources that are more accessible and less expensive. The consequence of this would be the continuation of illegal logging and deforestation. A company's long-term commitment to forest certification is a critical factor as it relates to the effectiveness and permanence of forest certification impacts on the environment. A company's commitment to forest certification is measured by the choice a certified company would make when its current certificate expires.

Company size, based on annual sales, is an important factor in a company's commitment to certification. The process of improving environmental practices and choosing to be certified is costly. These additional costs (transaction costs) could be significant to small-sized businesses because they would raise unit production costs, which affect its market competitiveness. Larger companies are better positioned to absorb these additional costs due to large-scale production volumes that spread the costs of certification over more units. A company's experience is another factor that could contribute to whether a company stays committed to certification or not. Previous research has found that a company's initial responses to strict regulatory environments are often different than their long-term responses (Cashore and Vertinsky 2000). This study explores how a company's experience will impact its future choice of forest certification. A company's experience was examined by its number of years operating in the industry and by the years of operation as a FSC-certified business.

\section{Research Methods and Data Analysis Methodology}

The unit of analysis in this study is an individual company in China and Vietnam that has obtained an FSC-COC certifi- 
cate. These companies represent almost all sectors within the forest products industry, including furniture, flooring, paper and printing, as well as general trading organizations and distributors. FSC maintains an online searchable database (www.fsc-info.org) for public access, and each certificate holder's contact, product information, and summary auditing reports (for FM only) can be found. As of Feb 10, 2009, when this study was started, 679 companies in China and 165 companies in Vietnam were listed on the Web site as valid FSC-COC certificate holders. In addition, another 15 companies in China and one company in Vietnam were listed as both FSC-FM and FSC-COC holders. Contact information of these companies was extracted from the Web site, and 551 companies in China and 93 companies in Vietnam were accessible via e-mail, which was used as the distribution method of this survey.

\section{Survey design and data collection}

Survey questions were developed in English and based on an extensive review of past research on forest certification, marketing and business management. After an internal review by professionals from industry and academia, the survey was translated into Chinese and Vietnamese. A pre-test was conducted with three Chinese companies and one Vietnamese company. There were no problems reported regarding either content or translation. The survey was then uploaded to www.Surveymonkey.com, a commercial online survey Web site, and made available in three language versions: Chinese, Vietnamese, and English.

E-mail invitations with an online survey link were sent to Chinese companies as identified above followed by two separate reminders e-mailed to those who did not respond to the initial invitation. Due to a delay in translation and review for the Vietnamese survey, the first invitation was sent to Vietnamese respondents a few days later and was followed by two more reminder e-mails. A total of 128 responses from China and 28 responses from Vietnam were collected. The small sample size from Vietnam resulted in an additional 30 Vietnamese companies being contacted. These were newly certified after the initial round of surveys and generated six more responses for a total of 34 . The final response rates were $23.2 \%$ for China and $27.6 \%$ for Vietnam (Tables 1 and 2).

\section{Results}

\section{Respondent profile}

Most COC firms in China and Vietnam are located in close vicinity to industry clusters. In China, almost half of the COC firms are located in Guangdong (30.5\%) and Zhejiang (15.6\%) provinces-the largest wood-processing and exporting bases in the country-while in Vietnam, Binh Dinh Province accounted for $50 \%$ of the total respondents, followed by Ho Chi Minh City (HCMC) (9\%). Similar patterns of regional concentration were observed in the sample data collected from each country, suggesting that these samples provide a good representation of the industry population.

Responding firms represented a variety of sectors within the forest products industry, with more than half (55\%) operating in wood products manufacturing, followed by trading firms and printing companies. Chinese respondents covered a wide range of business types, including wood manufacturing (47\%), printing (14\%), trading and distribution (13\%), and paper products (10\%). Vietnamese respondents were mainly from the wood manufacturing sector $(85 \%)$. Wood products manufacturers were asked to specify product groups they were manufacturing. The results show that Chinese wood manufacturers were producing a diverse range of products, led by indoor furniture, flooring, wood panels, and wood handicrafts, while outdoor furniture was the largest product group produced by the Vietnamese wood manufacturers.

On average, responding firms had over 10 years of experience in the forest industry, and 2.5 years as FSC-COC operations. Vietnamese companies reported a significantly longer history of FSC-COC operations (3.9 years) than their Chinese colleagues ( 2.2 years); this was significant at the alpha $p$ $<0.05$ level of significance, even though Vietnamese companies had less industry experience ( 7.4 years) than those in China (11 years).

Chinese companies on average were larger than Vietnamese companies in terms of annual sales for 2008. Around one-third of the Chinese companies were medium-sized operations with sales between $\$ 5$ million to $\$ 10$ million per year, and another third were large firms with sales over $\$ 10$ million per year. For most companies, the sales from FSClabeled products were only a small percentage of total sales. FSC sales for $59 \%$ of the Chinese companies accounted for about $1 \%$ to $25 \%$ of their total sales, while $26.5 \%$ of Chinese companies reported zero FSC sales. Vietnamese companies appeared to have an even distribution, with 20 companies covering all levels of FSC sales from 0 to $100 \%$.

\section{Perceived benefits of FSC}

Respondents were asked to rate a list of suggested FSC benefits based on 1-7 scale $(1=$ not helpful at all to $7=$ most helpful). Chinese and Vietnamese responses showed interesting disparities and similarities. "Support sustainable forestry" and "meet corporate social responsibility goals" were listed as the top two benefits of FSC by the Chinese respondents, while "price premium" benefits were rated much lower (Fig. 1). This suggests that environmental and social benefits of FSC are widely recognized by Chinese companies, while FSC's market-related benefits are not.

Vietnamese respondents rated "reduce business risks" as the top FSC benefit followed by "meet corporate social responsibility goals" and "meet buyer's requirements". These results showed that the largest disparity between China and Vietnam was with their perceptions of FSC as a tool to alleviate business risks by removing illegal timber from the supply chain. Vietnamese companies appeared to be more aware of the potential impact of timber legality issues on their supply chain. Chinese companies' lack of awareness of this risk may explain why none of the Chinese respondents had obtained legal verification, while $20 \%$ of Vietnamese respondents did obtain verification. Chinese companies had more environmental certificates on average than their Vietnamese colleagues. Significant perceptional differences were observed with the following three benefits- "support forest-dependent communities", "achieve higher management efficiency", and "achieve product differentiation"-all of which Vietnamese companies rated significantly higher than Chinese respondents. Despite these differences, there were some interesting similarities between Chinese and Vietnamese companies. 


\begin{tabular}{|c|c|c|c|c|c|}
\hline China & $\begin{array}{l}\text { Target respondents } \\
\text { (with valid e-mail) }\end{array}$ & $\begin{array}{l}\text { Increase in \# } \\
\text { responses }\end{array}$ & Response rate & $\begin{array}{c}\text { Total \# responses } \\
\text { collected } \\
\text { (cumulative) }\end{array}$ & $\begin{array}{c}\text { Response rate } \\
\text { (cumulative) }\end{array}$ \\
\hline First E-mail (Mar 5) & 551 & 46 & $8.3 \%$ & 46 & $8.3 \%$ \\
\hline Second E-mail (Mar 20) & 505 & 55 & $10.9 \%$ & 101 & $18.3 \%$ \\
\hline Third E-mail (Apr 1) & 450 & 27 & $6.0 \%$ & 128 & $23.2 \%$ \\
\hline
\end{tabular}

Table 2. Survey Response from Vietnam

\begin{tabular}{|c|c|c|c|c|c|}
\hline Vietnam & $\begin{array}{l}\text { Target respondents } \\
\text { (with valid e-mail) }\end{array}$ & $\begin{array}{l}\text { Increase in \# } \\
\text { responses }\end{array}$ & Response rate & $\begin{array}{c}\text { Total \# responses } \\
\text { collected } \\
\text { (cumulative) }\end{array}$ & $\begin{array}{c}\text { Response rate } \\
\text { (cumulative) }\end{array}$ \\
\hline First E-mail (Mar 10) & 93 & 13 & $14.0 \%$ & 13 & $14.0 \%$ \\
\hline Second E-mail (Mar 23) & 80 & 8 & $10.0 \%$ & 21 & $22.6 \%$ \\
\hline Third E-mail (Apr 1) & 72 & 7 & $9.7 \%$ & 28 & $30.1 \%$ \\
\hline Additional survey (Sep 15) & 30 & 6 & $20 \%$ & 34 & $27.6 \%$ \\
\hline
\end{tabular}

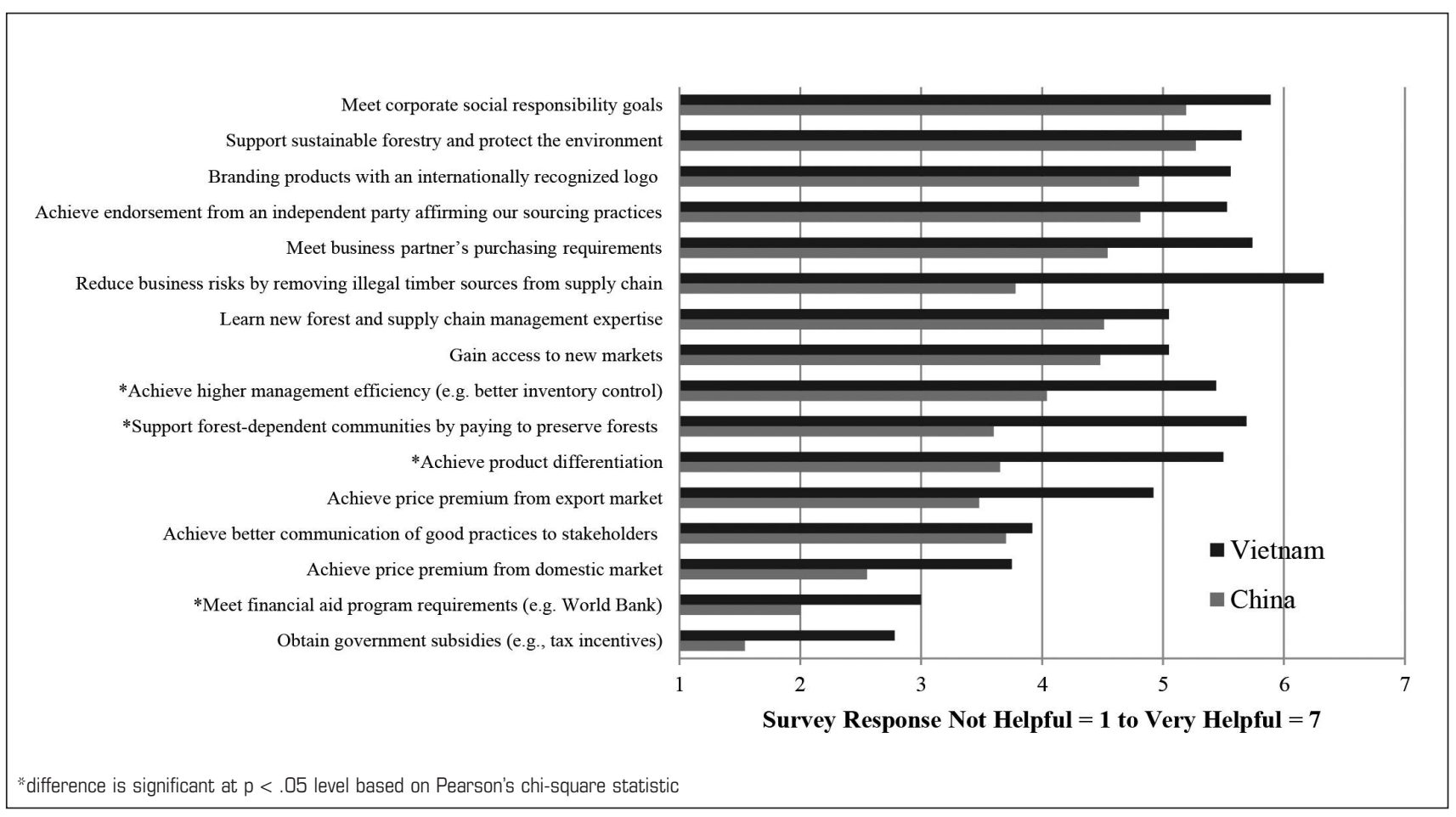

Fig. 1. Vietnamese and Chinese respondents' ratings of FSC benefits.

Both groups put FSC's social and environmental benefits higher that its market benefits (price premiums). These were seen as the most valuable features of FSC, while they did not seem to appreciate how FSC certification could bring government subsidies and low interest loans from international banking institutes.
Perceived challenges to FSC-COC operations

Survey respondents were asked to identify challenges to their FSC-COC operations from a list of seven major constraints revealed by previous literature and the field experience from authors of this study. Results showed that "shortage of FSCcertified raw material supply", "low market awareness of FSC- 
labeled products", and "high certification cost" were the top three challenges reported. This was followed by "lack of market incentives" and "lack of technical support", while factors relating to certification bodies (auditing process and service quality) were lesser challenges (Fig. 2).

There was some variation in the rankings of these challenges between countries. Almost half of the Vietnamese respondents saw "high certification cost" as a challenge, while it was not as much of a problem to Chinese respondents. Chinese companies ranked "low market awareness" and "lack of market incentives" to be of concern, but these were not ranked as high for Vietnamese respondents. Other constraints encountered by respondents included business "partners' low awareness of FSC", and "few FSC products varieties".

\section{Long-term commitment to forest certification}

As the target population of this survey was FSC-COC certificate holders in China and Vietnam, the commitment to forest certification is defined by whether or not these companies will choose to stay certified after their current certificate expires. There were five collectively exhaustive and mutually exclusive options from which respondents could choose:

1. Renew current certificate and stay as an FSC-certified company.

2. Switch to a different forest certification scheme.

3. Renew current certificate but also add another certification (multiple certification).

4. Do not renew or pursue any type of forest certification.

5. Not sure.

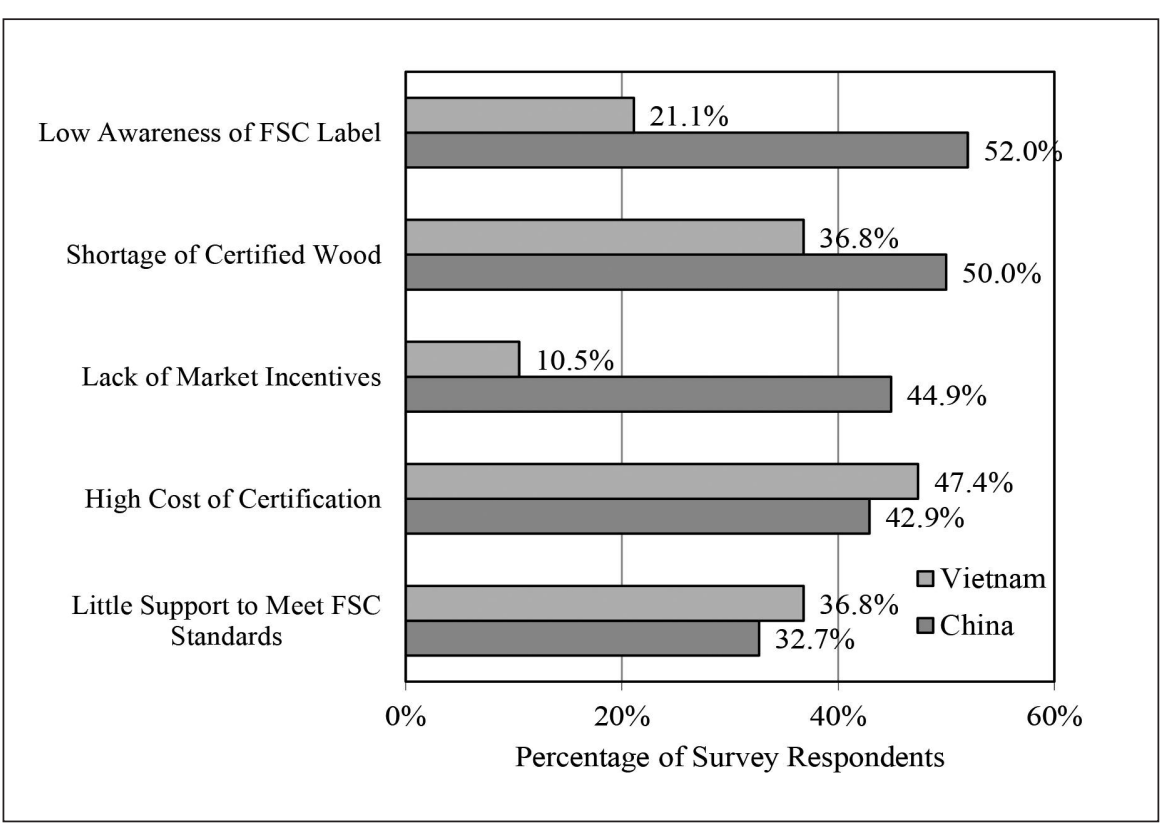

Fig. 2. Challenges to FSC-COC operations in China and Vietnam.

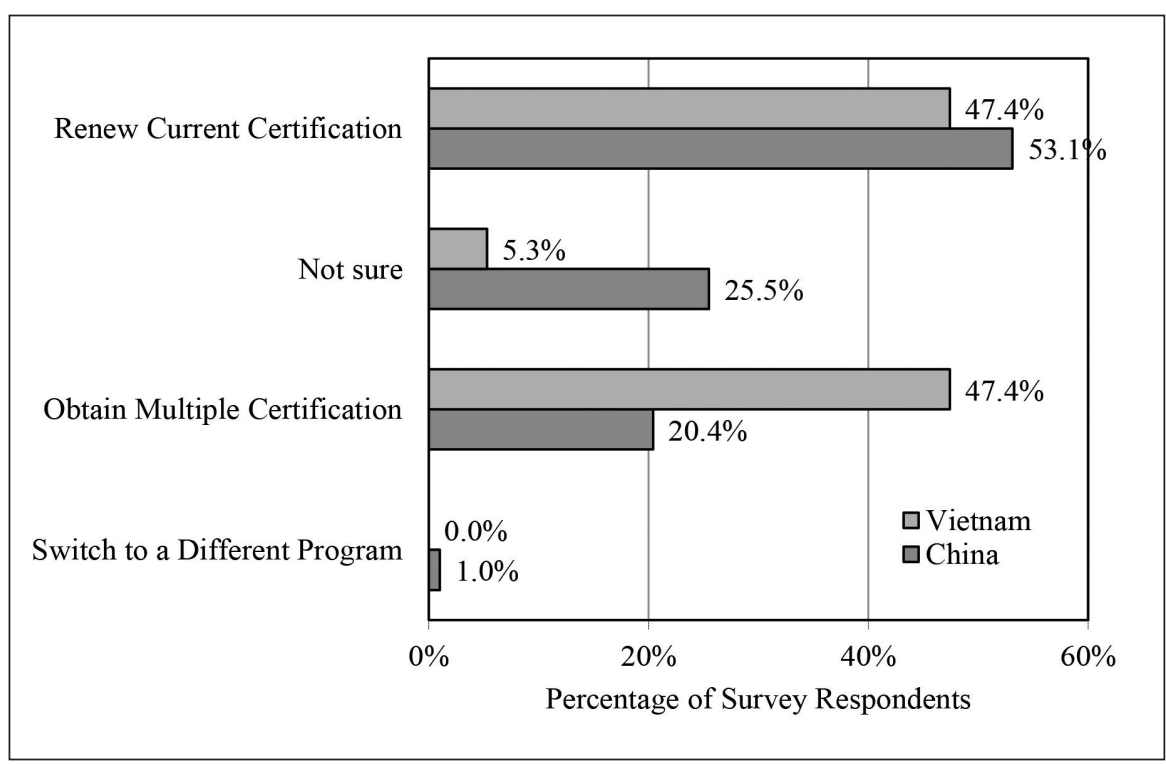

Fig. 3. Intention when current certification expires.
The results showed that a majority of respondents had clear intentions to stay certified after their certificates expire (Fig. 3). Among the total of 118 respondents, over half (61) chose to stay with FSC after their current certificates expire, and another 25\% (29) of the respondents chose to go and pursue another type of forest certification, in addition to FSC. Approximately $23 \%$ of the respondents (26) chose "Not sure". The choices to switch or not renew received only one selection each.

Based on these responses, two groups were formed, a "Committed Group" consisting of $77 \%$ of the total respondents with demonstrated intention to stay certified (Choices 1 and 3); and an "Undecided Group" consisting of $22 \%$ of the total respondents who were more uncertain of their future forest certification plans. The choice to switch or not renew were not included in the follow-up analysis due to the small sample size.

Based on these results, FSC should work to significantly improve its market-based incentives for industry members so they continue to choose certification. These incentives, plus additional environmental and social-related performance benchmarks of current certified industry members, could help in retaining certification for much of this region while helping to keep its attractiveness to customers. With an increasingly strict regulatory environment, particularly with the amended Lacey Act and EU FLEGT in place, industry's long-term commitment to forest certification will need continual observation. 


\section{Conclusion}

China and Vietnam combined process nearly one-half of the world's forest products, but less than $1 \%$ of the worlds' certified forests are located in these regions. The adoption of forest certification by local industries in China and Vietnam and their long-term commitment to responsible and sustainable sourcing practices have significant implications to the global forest products industry.

As the most widely supported forest certification scheme in the world, FSC is being increasingly adopted by local industries in China and Vietnam. The demand for FSC-FM will be fueled by the non-government sector. In terms of the number of FSC-COC holders, China is now the largest country in Asia with 2001. A similar trend can be expected in Vietnam, which has become the fourth-largest wood furniture exporter in Asia. Vietnam currently has only 10000 ha of FSC-certified forests (plantations), but it has 270 FSC-COC certificate holders, with many of those being outdoor furniture manufacturers. The rise in the demand for forest certification and certified products in China and Vietnam will continue to be driven by increasingly strict regulations and customers' environmental agendas.

Consistent with findings by previous research (e.g., Yuan and Eastin 2007), the lack of raw material supply and low market awareness of FSC-labeled products were found to be major challenges encountered by FSC-COC companies in China and Vietnam. High certification costs appear to be a major challenge and the top challenge for Vietnamese companies. These challenges are closely linked to each other and are rooted in one common factor, this being a lack of local capacity and market-support systems that link the entire supply chain together. During field interviews in China, many COC companies either had no FSC production at all or were reliant on expensive imports to maintain their FSC production, which could result in up to $30 \%$ higher production costs. Not all industry buyers are ready to pay higher prices for certified products, although many of them are pushing their suppliers to pursue FSC. Many buyers are starting to provide a certain level of technical and financial assistance to support this movement. These challenges of certification could dilute the attractiveness of FSC and therefore discourage companies from staying committed to forest certification for the long term. With certain strategies in place certification organizations could increase awareness and help with market-based incentives for companies to continue their commitment to FSC and other certification programs.

\section{References}

Aguilar, F.X. and R.P. Vlosky. 2008. Forest certification descriptions as instruments for branding: an exploratory analysis of US supply chain members. Forest Products Journal 58(3): 26-33.

Bael, D. and R.A. Sedjo, 2006. Toward globalization of the forest products industry. Discussion Paper, Resources for the Future. Washington, DC.

Butler, R.A. 2009. Vietnam outsources deforestation to neighboring countries [online]. Available at Mongabay.com http://news. mongabay.com/2009/0902-vietnam.html.

Cashore, B., G. Auld and D. Newsom. 2004. Governing Through Markets: Forest Certification and the Emergence of Non-State Authority. Yale University Press, New Haven and London. 327 p.

Cashore, B., F. Gale, E. Meidinger and D. Newsom. 2006. Forest certification in developing and transitioning countries: part of a sustainable future? Environment 48(9): 6-25.

Cashore, B. and I. Vertinsky. 2000. Policy networks and firm behaviors: governance systems and firm responses to external demands for sustainable forest management. Policy Sciences 33: 1-30.

de Jong, W. 2010. Forest Rehabilitation and its Implication for Forest Transition Theory. Biotropica 42(1): 3-9.

EIA/Telepak. 2008. Borderlines: Vietnam's booming furniture industry and timber smuggling in the Mekong region. Environment Investigation Agency (EIA) and Telepak. 21 p. Available at http:// www.illegal-logging.info/uploads/Borderlines.pdf.

[FAO] Food and Agriculture Organization. 2005. Global forest resources assessment 2005.Available at http://www.fao.org/docrep/ 008/a0400e/a0400e00.htm.

[FSC] Forest Stewardship Council. 2009. Milestones - Annual report 2009. Available at http://www.pourquoilepapier.com/PIOP/ files/d2/d25c0432-4d57-45fa-a903-eefc64d453ba.pdf.

2012. Global FSC certificates: type and distribution May 2012.Available at http://www.fsc.org/facts-figures.19.htm.

Karna, J., E. Hansen and H. Juslin. 2003. Environmental activity and forest certification in marketing of forest products - a case study in Europe. Silva Fennica 37(2): 253-267.

Owari, T., H. Juslin, A. Rummukainen and T. Yoshimura. 2006. Strategies, functions and benefits of forest certification in wood products marketing: perspectives of Finnish suppliers. Forest Policy and Economics 9(4): 380-391.

Vidal, N., R. Kozak and D. Cohen. 2005. Chain of custody certification: an assessment of the North American solid wood sector. Forest Policy and Economics 7(3): 345-355.

The World Bank. 2008. Forests Sourcebook: Practical Guidance for Sustaining Forests in Development Corporation. 402 p. Available at http://siteresources.worldbank.org/EXTFORSOUBOOK/Resources /completeforestsourcebookapril2008.pdf.

Yuan, Y and I.L. Eastin. 2007. Forest certification and its influence on the forest products industry in China. CINTRAFOR Working Paper\# 110. University of Washington, Seattle, WA. 